\title{
HORTICULTURAL GROWERS' WILLINGNESS TO ADOPT RECYCLING OF IRRIGATION WATER
}

\author{
ALYSSA CULTICE \\ U.S. Environmental Protection Agency, Office of Solid Waste and Emergency Response, Arlington, Virginia; and \\ Department of Agricultural and Applied Economics, Virginia Tech, Blacksburg, Virginia \\ DARRELL J.BOSCH* \\ Department of Agricultural and Applied Economics, Virginia Tech, Blacksburg, Virginia \\ JAMES W. PEASE \\ Department of Agricultural and Applied Economics, Virginia Tech, Blacksburg, Virginia \\ KEVIN J. BOYLE \\ Department of Agricultural and Applied Economics, Virginia Tech, Blacksburg, Virginia \\ WEIBIN XU \\ Department of Agricultural and Applied Economics, Virginia Tech, Blacksburg, Virginia
}

\begin{abstract}
Recycling irrigation water can provide water during periods of drought for horticulture operations and can reduce nonpoint-source pollution, but water recycling increases production costs and can increase risk of disease infestation from waterborne pathogens such as Pythium and Phytophthora. This study of water recycling adoption by horticultural growers in Virginia, Maryland, and Pennsylvania finds that the potential for increased disease infestation would reduce growers' probability of adopting water recycling. Widespread adoption of recycling irrigation water would require government incentives or coercion or growers' ability to pass cost increases on to customers.
\end{abstract}

Keywords. Choice experiment, horticulture, irrigation, mail survey, Phytophthora, Pythium, water recycling

JEL Classifications. Q12, Q51, Q52

\section{Introduction}

Irrigation water management is an important consideration for horticulture operations. For the nation as a whole, approximately $52 \%$ of horticultural

This work was supported by the U.S. Department of Agriculture, National Institute of Food and Agriculture, Hatch project 227572, and by Specialty Crop Research Initiative Project \#2010-5118121140, "Integrated management of zoosporic pathogens and irrigation water quality for a sustainable green industry." The authors appreciate the research assistance of Nicole D'Alessio and Gwen Rees.

*Corresponding author: e-mail: bosch@exchange.vt.edu 
operations rely on irrigation (U.S. Department of Agriculture [USDA], 2014a, 2014 b, 2014c). Horticulture operations that depend on surface water or groundwater for irrigation can be substantially affected by water shortages in times of drought, such as the drought being experienced currently in the western United States. One approach that can mitigate risks of water shortages is for growers ${ }^{1}$ to capture and reuse irrigation water.

Although growers may be concerned about water scarcity, policy makers are concerned with water quality and seek to improve water quality by reducing nonpoint-source (NPS) pollution. In December 2010, the U.S. Environmental Protection Agency (USEPA) in collaboration with states comprising the Chesapeake Bay watershed (Virginia, Maryland, Delaware, West Virginia, Pennsylvania, and New York) and the District of Columbia established a total maximum daily load (TMDL) for nitrogen $(\mathrm{N})$ and phosphorus $(\mathrm{P})$ in each tributary emptying into the Chesapeake Bay (USEPA, 2010). USEPA took action to ensure that pollution control measures needed to fully restore the bay and its tidal rivers would be in place by 2025 .

Horticulture operations are one source of NPS pollution loadings due to runoff from storm events and irrigation, and such operations will be under scrutiny to reach pollution reduction goals. For example, Virginia is committed to the TMDL goal that $95 \%$ of the land area of container nurseries and greenhouses will have practices in place that capture irrigation and storm water runoff up to the volume of a 1-inch storm event (Commonwealth of Virginia, 2010). ${ }^{2}$ There is an expectation that these operations will reduce their $\mathrm{N}$ and $\mathrm{P}$ loadings as a result of irrigation and storm water capture, water recycling, and implementation of other water conservation practices.

Reducing runoff from horticultural operations is an important agricultural issue in the Mid-Atlantic region. In Maryland, Pennsylvania, and Virginia (our study area), sales from crop agriculture were $\$ 5.2$ billion in 2012, and the green industry constituted $28 \%$ of sector sales (USDA, 2014a, 2014c). In addition, this is an issue of national importance as agricultural and environmental groups in other significant watersheds around the United States are watching the Chesapeake Bay initiatives as actions that might be applied in their regions in the future (Valentine, 2015).

If the potential for drought motivates growers to capture irrigation and storm water, then this could be a natural incentive (nudge) to reduce NPS pollution loadings from their operations (Czap et al., 2015). However, nationally, as well as in the Chesapeake Bay watershed, only approximately $5 \%$ of

1 We will refer to horticulture operations' decision makers as "growers" in the remainder of this article.

2 The goal stops short of containing all runoff because it would be difficult or impossible for operators to capture all runoff from an extreme storm event such as a hurricane. 
growers recycle irrigation water (USDA, 2014b). This low rate of water recycling may be the result of a number of considerations. Some growers may have constrained production areas, and setting aside land for recycling infrastructure may be physically challenging or impossible. Further, the capital costs of grading field topography to capture storm and irrigation runoff, and of constructing the associated holding ponds, can be substantial (Ferraro, 2015).

Another important concern is increased plant disease risks from the use of recycled water. Water recycling can pose increased risk of disease caused by the waterborne pathogens Pythium and Phytophthora. Pythium primarily affects the roots of greenhouse plants and causes root rot (Moorman, 2013a). Phytophthora can cause root rot as well as stem rot or cankers on plants grown in pots outdoors (Moorman, 2013b). Both pathogens can affect plants throughout all stages of growth and are capable of killing a variety of ornamental crops. Even though no comprehensive data exist, it is estimated that waterborne plant pathogens, such as Pythium and Phytophthora, may cause crop losses of up to $12 \%$ in the United States annually (Pimentel et al., 1997). Irrigation water recycling, without measures to remove pathogens from the water, can result in the continual reinoculation of horticulture crops with diseases and increase crop losses (Hong and Moorman, 2005). Although the potential for water shortages could be a natural nudge to recycle irrigation water, the potential for losses due to disease can be a natural disincentive to recycle.

The purpose of this research is to evaluate horticulture operations' willingness to adopt water recycling as a function of increased production costs, water shortage risks, and disease risks. If growers are strongly concerned with water shortages, then this concern should provide a nudge to capture irrigation and storm runoff as a water insurance action. If growers are further not concerned about the spread of plant diseases from recycling, perhaps because they already have the infrastructure in place to control waterborne diseases, then policy makers may simply need to educate growers about recycling to nudge adoption of this environmentally desirable behavior.

Grower responses to these drought and disease risks are not known and need to be investigated. The study was carried out with a mail survey of ornamental horticulture operations in Maryland, Pennsylvania, and Virginia to investigate water recycling adoption. The results show that production costs and disease risks significantly reduce growers' willingness to adopt water recycling. Adoption of water recycling is not influenced by risks of water shortages. This may be because recent droughts have already forced growers to secure sufficient water resources to meet irrigation needs during periods of water shortages. Thus, policy makers may need to take proactive measures through coercive or incentive policies to encourage water recycling as a mechanism to reduce NPS pollutant discharges from horticulture operations. 


\section{Methods and Data}

Growers were asked if they would choose to invest in (adopt) water recycling in the face of differing levels of water shortage risks, plant disease risks, and changes in production resulting from the decision to capture and recycle water runoff from irrigation and storm events. A choice-experiment survey was designed to investigate these choices by growers: willingness to invest in water recycling in the presence of increased production costs and differing levels of drought and disease risks. The survey was implemented by mail. Data analyses are based on respondents who irrigate but do not recycle $100 \%$ of their irrigation water.

\subsection{Survey Design}

The tailored design method was utilized to develop and administer the mail survey (Dillman et al., 2008). The initial survey design was based on input from horticulture experts in academia and industry. This involved meetings with plant pathologists and an industry advisory group that were part of the research project; a series of 10 site visits with growers in Maryland, Pennsylvania, and Virginia; and a focus group conducted with two growers and three horticultural extension agents. The final survey included questions about the growers and their operations and two choice questions about irrigation water recycling.

The survey was administered by mail and designed to take approximately 15 minutes to complete. A letter of introduction and the survey were distributed on February 21, 2013, followed by a reminder postcard on February 28, 2013, and a second reminder postcard on March 7, 2013. A second round of surveys was sent to nonrespondents on March 12, 2013.

\subsection{Choice-Experiment Questions}

Choice questions are widely used to understand how consumers and producers might respond to a set of proposed conditions (Holmes and Adamowicz, 2003; Omondi et al., 2008; Scarpa et al., 2003a, 2003b; Zander and Drucker, 2008). The key purpose of the survey was to understand growers' willingness to adopt irrigation water recycling in the face of possible water shortages and potential for transmission of plant diseases. To introduce the choice experiment, we presented survey participants with information about capturing irrigation water, recycling captured water, and the potential for water shortage and plant disease (Phytophthora/Pythium) risks (Figure 1). This information was intended to reinforce to respondents that the choice presented was a realistic investment choice that they could make in the future in response to possible environmental requirements. The choice-experiment questions had two recycling alternatives and three attributes (disease risk, water shortage risk, and increased production costs) (Figure 2).

The "disease" attribute refers to the probability of detecting plants infected with the pathogens Phytophthora or Pythium. The baseline (current detection 
Table 1. Choice-Experiment Attributes and Levels

\begin{tabular}{ll}
\hline \hline Attributes & Levels \\
\hline Probability of annual disease detection & $10 \%$ (current condition), 12\%, 14\%,16\%, 18\%, 20\% \\
Probability of annual water shortage & $10 \%, 13 \%, 15 \%$ (current condition), 17\%, 20\% \\
Percent increase in annual nursery & $5 \%, 10 \%, 15 \%, 20 \%$, (no change) \\
$\quad$ production costs for installing and & \\
$\quad$ operating water recycling & \\
\hline \hline
\end{tabular}

New state and federal regulations designed to improve water quality might require nursery and greenhouse producers to capture all irrigation water and runoff from storms. Capture means impeding water runoff from your operation so that it does not flow directly to adjacent property or streams.

In addition to capturing irrigation water runoff, operations may choose to recirculate this captured water for irrigation purposes. Factors that could have an impact on the choice to recycle $100 \%$ of their water include disease risk, risk of irrigation water shortage, and costs of recycling.

\section{Risk of plant disease}

Disease risk refers to the probability of plants developing Pythium/Phytophthora disease if irrigation recycling were implemented on your operation. This is the probability of plants showing disease symptoms in a typical year. Recycling stored water runoff for irrigation poses the potential problem of transferring diseases back to crops. An industry baseline for disease probability is assumed to be $10 \%$. If a producer invests in water recycling, one of the components of the system would attempt to control for Pythium/Phytophthora.

\section{Risk of irrigation water shortage}

Risk of irrigation water shortage refers to a shortfall in water supply caused by depleted private or public well water or falling stream or pond levels. In recent years, producers around the country have experienced severe heat and drought conditions that have caused irrigation water shortfall. An industry baseline for irrigation water shortfall is assumed to be $15 \%$. In $15 \%$ of the years between 1895 and 2000 , cumulative rainfall was at or below $1.75^{\prime \prime}$ in your region during April-August posing a water supply problem for some producers.

\section{Increased cost of installing and operating recycling}

Many operations are not currently equipped to comply with a "capture" regulation or recycle irrigation water without incurring additional costs.

\section{Figure 1. Information on Choice Attributes that Preceded Choice Questions in the} Survey

The table below is an example of a recycling scenario question. The table describes two alternative situations where you have the option to implement water recycling at your operations with the risks defined by the given probabilities.

rate) was $10 \%$, and this attribute level was increased in $2 \%$ increments up to $20 \%$ to reflect the potential increase in disease incidence associated with water recycling (Table 1 ). The disease probability of $20 \%$ is the maximum level of disease detection beyond which experts considered that an operation would be unlikely to stay in business. The survey made clear that this is the probability of pathogen detection, not a $20 \%$ crop loss. 


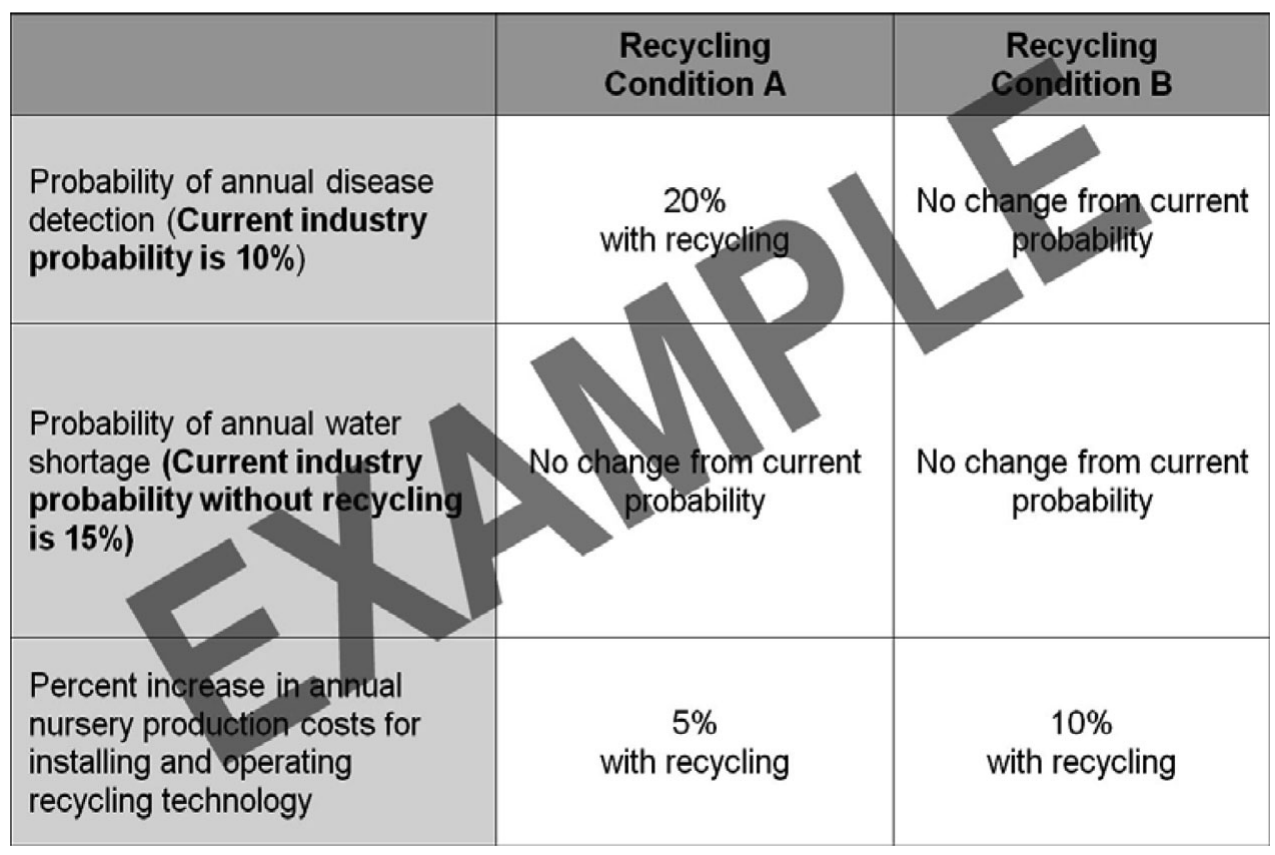

Figure 2. Example Choice Question

Would you choose to invest in 100\% water recycling if Condition A or Condition B occurred? (Circle one number response below the table.)

1 I would invest in recycling if Condition A occurred.

2 I would invest in recycling if Condition B occurred.

3 I would not invest if either Condition A or B occurred.

The "water" attribute is the probability of suffering a shortage of irrigation water due to low rainfall, which affects water availability from all sources. The National Weather Service monthly average cumulative precipitation for Virginia, Maryland, and Pennsylvania from 1895 to 2000 was used to estimate precipitation probabilities (National Oceanic and Atmospheric Administration, National Weather Service Internet Services Team, 2012). There is no universal definition of "water shortage" for horticulture operations. We assumed that if the average monthly precipitation during the April-August growing season falls below 1.75 inches (the 15th percentile of the historical rainfall distribution), then there may be a "water supply" shortage for some growers. The levels for this attribute were the baseline of $15 \%$ and decrements and increments to $10 \%$, $13 \%, 17 \%$, and $20 \%$ chances of monthly rainfall being less than 1.75 inches (Table 1). Allowing for the chance of rainfall to decrease or increase allows for some areas receiving more rain as the climate changes. This is a condition that some growers are already considering and added realism to the design of the choice-experiment scenario.

"Cost" refers to the percent increase in annual nursery production costs necessary to install and operate infrastructure for water recycling and disease 
control. Four levels were included in the design: $5 \%, 10 \%, 15 \%$, and $20 \%$ of annual nursery production costs (Table 1). Many operations have other business lines such as retail shops and landscaping services whose costs would not be affected by the water recycling activities. The baseline value for the cost attribute is $\$ 0$, no change in current operator practices if the grower chooses not to adopt.

Percent cost increases, rather than absolute increases, were used because of the large differences in the scale of horticulture operations. Some operations have total costs of less than $\$ 100,000$, and others have costs of more than $\$ 1,000,000$. A $\$ 100,000$ increase in cost for a grower with a $\$ 1,000,000$ operation would be a $10 \%$ increase in cost, but for the $\$ 100,000$ operation this would be an unrealistic $100 \%$ increase in operating costs. Conversely, a $\$ 10,000$ increase ( $10 \%$ for a $\$ 100,000$ operation) might be unrealistically small for a $\$ 1,000,000$ operation. Thus, using percentages allows the costs to be realistic for different size operations. Percent cost increases, rather than absolute increases, have been used in other applications where respondents would find it difficult to respond to absolute cost amounts (see Bederli and Brouwer, 2007).

In developing the choice experiment, we knew that among contacted nursery operations, not all operations would irrigate. Thus, the plan was to send surveys to every identified operation that we could contact. With this limited population, and consequently limited sample size, we kept the experimental design as simple as possible with three key policy/decision attributes and a limited number of levels while also providing realistic variation in the levels.

Using these attributes and levels, we developed a d-efficient design using Ngene (http://www.choice-metrics.com/). Collins, Rose, and Bliemer (2007) found that using d-efficiency improved statistical efficiency compared with traditional orthogonal designs. The final design had 20 choice sets with each survey having two choice questions; this resulted in 10 pairs of choice sets that were randomly assigned to surveys. The choice questions were limited to two per survey because we learned in the design process that growers were unlikely to answer more than two choice questions.

\subsection{Model Specification}

A conditional logit model was estimated using the responses to the choice question to model the probability of growers adopting water recycling technology as a function of choice-experiment attributes $(a)$ and grower characteristics $(c)$ :

$$
\operatorname{Pr}(\text { adopt })=f\left(a, c ; \beta_{a}, \beta_{c}\right)+\varepsilon,
$$

where $\beta_{a}$ and $\beta_{c}$ are vectors of coefficients to be estimated and $\varepsilon$ is a random error term of factors that influence grower choices but are not observable to the investigator. A random parameters logit model was also estimated to consider the robustness of the empirical results and to allow that respondents' answers to the two choice questions are likely to be correlated.

Two specifications of the equation are estimated: a "long model" and a "short model." In the long model, the levels of the water shortage and disease attributes 
are entered as binary variables: ${ }^{3}$

$$
\begin{aligned}
& f_{l m}\left(a, c ; \beta_{a}, \beta_{c}\right)=\beta_{\$}(\% \text { cost })+\beta_{10 \% w s}(10 \% \text { watershortage }) \\
& \quad+\beta_{13 \% w s}(13 \% \text { watershortage })+\beta_{17 \% w s}(17 \% \text { watershortage }) \\
& \quad+\beta_{20 \% w s}(20 \% \text { watershortage })+\beta_{12 \% d}(12 \% \text { disease }) \\
& \quad+\beta_{14 \% d}(14 \% \text { disease })+\beta_{16 \% d}(16 \% \text { disease })+\beta_{18 \% d}(18 \% \text { disease }) \\
& \quad+\beta_{20 \% d}(20 \% \text { disease })+\beta_{c} c
\end{aligned}
$$

where "\% cost" is a continuous variable coded as a proportion on the $(0,1)$ interval, the attribute level variables equal 1 when the specified level applies and 0 otherwise, $15 \%$ water shortage and $10 \%$ disease risk are omitted categories, and $c$ is the vector of grower characteristics. The short model collapses the water shortage and disease variables into a single binary variable:

$$
\begin{aligned}
f_{s m}\left(a, c ; \beta_{a}, \beta_{c}\right)= & \beta_{\$}(\% \text { cost })+\beta_{w s}(\uparrow \text { watershortage }) \\
& +\beta_{d}(\uparrow \text { disease })+\beta_{c} c,
\end{aligned}
$$

where $\uparrow$ watershortage equals 1 if water shortage equals $17 \%$ or $20 \%$ and 0 otherwise, and $\uparrow$ disease equals 1 if disease equals $12 \%, 14 \%, 16 \%, 18 \%$, or $20 \%$ and 0 otherwise. ${ }^{4}$ The $\uparrow$ watershortage and $\uparrow$ disease variables were distributed in the random parameters (mixed logit) estimation assuming normal distributions. ${ }^{5}$

The same set of grower characteristics is included in the long and short models:

$$
\begin{aligned}
\beta_{c} c= & \beta_{\text {own }}(\text { owner }) * \text { asc }+\beta_{\text {col }}(\text { collegedegree }) * \text { asc }+\beta_{\text {hrev }}(\text { highrevenue }) * \text { asc } \\
& +\beta_{\text {ews }}(\text { expwatershortage }) * \text { asc }+\beta_{\text {ed }}(\text { expdiseaseloss }) * \text { asc }
\end{aligned}
$$

where owner equals 1 if respondent owns the operation and 0 otherwise, collegedegree equals 1 if respondent has a four-year college degree and

3 Setting each attribute as a binary variable is the most flexible functional parametric specification to investigate the response patterns. This specification provides insights as to what the functional relationships might look like for watershortage and \%disease. We also ran linear, log, and quadratic specifications with watershortage and \%disease specified as continuous variables. Watershortage continues to be insignificant in the linear, quadratic, and log specifications; this is not surprising because this variable was insignificant for all binary variables. The disease variable is significant in the linear and $\log$ specifications, but not the quadratic specification. Neither the linear or log specifications fit the data as well as the binary specification; this again is not surprising because the coefficients on the binary variables do not suggest the response patterns follow linear or log relationships.

4 We investigated a model that includes an interaction term, $\uparrow$ watershortage $e^{*}$ disease, but this term was not significant, and the inclusion/exclusion of this interaction does not affect the estimated coefficients for the other variables in the model.

5 We attempted to estimate a random parameters logit for the long model, but estimation for this equation did not converge. 
0 otherwise, highrevenue equals 1 if operation annual revenue is greater than $\$ 250,000$, expwatershortage equals the number of times water shortage experienced $(1,2,4$, or 6$),{ }^{6}$ expdiseaseloss equals percent revenue loss from disease experienced $(0.5 \%, 1.5 \%, 4 \%, 8 \%, 15.5 \%$, or $25 \%),{ }^{7}$ and asc equals 1 if recycling condition A or B (see Figure 2) was chosen and 0 otherwise. These grower characteristics were selected based on empirical results from the survey that are discussed subsequently.

The grower characteristics that are interacted with the alternative-specific constant capture whether there are individual characteristics, aside from the choice-experiment attributes, that would make a respondent more or less likely to adopt water recycling. That is, positive significant coefficients indicate that respondents have a predisposition to invest in recycling that is not motivated by the attributes in the choice questions and that negative, significant coefficients would indicate the opposite.

\subsection{Sampling}

The mail survey focused on ornamental nursery operations in Virginia, Maryland, and Pennsylvania that irrigate but do not capture and recycle all applied irrigation water. According to the 2007 Census of Agriculture, ${ }^{8}$ there were 4,785 greenhouse, nursery, and floriculture production operations in this tristate region (1,085 in Virginia, 673 in Maryland, and 3,027 in Pennsylvania) (USDA, 2009). ${ }^{9}$ Operations included in the current study have field and/or container nursery production. There were a total of 1,620 operations that fit this condition (947 in Pennsylvania, 281 in Maryland, and 392 in Virginia). Of these operations, 592 reported irrigating nursery crops in field settings.

One approach to contacting these operations would be to team with the National Agricultural Statistics Service (NASS) to develop a sample and conduct the survey. This was not possible because NASS was in the process of conducting the periodic Census of Agriculture and was concerned with respondent burden and confusion from growers receiving two survey instruments at approximately the same time. Further, the NASS population only includes operations that receive more than $50 \%$ of their total receipts from greenhouse, nursery, and floriculture products, which would omit some of the growers in the population we desired to survey (USDA, 2014a).

6 This variable was collected using categories of 0 (never), 1-2, 3-4, and 5 or more times experiencing irrigation water shortage.

7 This variable was collected using categories of $<1 \%, 1 \%-2 \%, 3 \%-5 \%, 6 \%-10 \%, 11 \%-20 \%$, and $>20 \%$.

8 The 2012 Census of Agriculture was not available when the research was initiated.

9 Operations included in this total include farms that receive more than $50 \%$ of their total receipts from greenhouse, nursery, and floriculture products and are classified as NAICS (North American Industry Classification Standards) number 1114. 
Table 2. Mail Survey Response Data

\begin{tabular}{lc}
\hline \hline Survey Characteristics & Result \\
\hline Number of operations identified & 3,339 \\
Operations eliminated by telephone screening & 1,304 \\
Surveys mailed & 2,035 \\
Surveys returned as undeliverable & 265 \\
Delivered surveys & 1,770 \\
Surveys returned & 435 \\
Response rate as a percent of delivered surveys & $25 \%$ \\
Surveys from irrigated operations & 259 \\
Surveys from irrigated operations with usable responses to the choice questions & 195 \\
Choice question responses & 387 \\
\hline \hline
\end{tabular}

${ }^{\text {a }}$ Respondents eliminated because they did not have an outdoor ornamental nursery with irrigation $(1,141)$, were no longer in business (57), and did not wish to be surveyed (103) or other reason (3).

${ }^{\mathrm{b}} \mathrm{A}$ total of 192 respondents answered both choice questions, and 3 respondents only answered one of the two choice questions in their surveys.

Thus, there was not a documented population of horticulture businesses in the study area to sample. In turn, we carefully documented the process followed to develop the sample used to implement the study.

First, mailing addresses and phone numbers were obtained for Maryland, Pennsylvania, and Virginia operations through publicly available information on permitted nursery operations ${ }^{10}$ and public listings such as Nursery Trees and Garden Guides. ${ }^{11}$ These lists were cross-checked with available mailing lists from nursery business associations in Virginia and Maryland. ${ }^{12}$ The effort resulted in a list of 3,339 nursery operations in the three-state area (Table 2).

The 3,339 nursery businesses might include operations that do not meet the criteria for inclusion in the study (e.g., they do not irrigate). Thus, telephone screening calls were made to identify operations that met the conditions for inclusion in the study. The conditions for inclusion in the study were an outdoor production area, with or without containers, and the use of irrigation. Telephone interviewers attempted to contact all 3,339 potential operations using up to five callbacks if initial contacts were not successful.

When a contact was made, the interviewer requested the name and mailing address of the individual in the organization who was responsible for the

10 Virginia Department of Agriculture and Consumer Services, Virginia Department of Agriculture and Consumer Services Permit System - Registrants with Active Permits: Category 91 - Nursery Operation (http://www.vdacs.virginia.gov/pdf/91nursery.pdf); Maryland Department of Agriculture (http://mda.maryland.gov/plants-pests/Documents/md_nurs_alpha.pdf).

11 NurseryTrees.com, "Nurseries and Garden Centers in Virginia" (http://www.nurserytrees. com/States/state\%20Virginia.htm); Garden Guides Directory (http://www.GardenGuides.com).

12 Virginia Nursery Landscape Association, the Maryland Nursery Landscape Association, and the Maryland Greenhouse Growers Association. 
production and financial decisions of the business. There were 362 operations in the "complete" category: operations that responded to calls, said they would complete the survey, and gave mailing information. Operations that could not be reached by telephone were included in the final mailing in the event that they were closed for the winter when screening calls were made. The final list included 2,035 surveys mailed with 1,770 having valid addresses (Table 2).

For this study, with no known population or population statistics, there is not a criterion to assess the representativeness of the sample statistics. Thus, we followed best survey practices, which we have documented in this section, to establish the content validity of the survey sample (Carmines and Zeller, 1979).

\section{Results}

A total of 435 surveys were returned for a response rate of $25 \%$ (Table 2). Of the returned surveys, 259 were from operations that irrigate. Not all respondents answered the choice questions, some respondents selected two responses to a choice question when only one was allowed, and three respondents answered the choice questions but already recycled $100 \%$ of their irrigation water. These types of respondents were removed from the data used for the analyses reported in this study. This left 192 respondents who answered both choice questions and an additional 3 who answered one of the two choice questions (387 choicequestion responses). In total, 50 respondents selected "would invest" (adopters) for at least one choice question, and 148 chose "would not invest" (nonadopters) for all their responses to the choice questions.

\subsection{Characteristics of Respondents}

Adopters averaged approximately the same years of experience (26) as nonadopters (25) (Table 3). Most respondents were owners (84\%), and a majority of respondents had a college education (55\%). Operation revenue was asked using categories, as is done in personal surveys, so that growers would be more likely to answer this sensitive question. Operation revenue from all sources varied widely across firms, ranging from less than $\$ 25,000$ to more than $\$ 10,000,000$ (Table 3). Nonadopters tended to be very low revenue firms. Respondents were more forthcoming about cost information and were asked to report total production costs and only those costs associated with their nursery operations. Adopters had higher total production costs and higher nursery costs compared with nonadopters (Table 3).

Most respondents reported losses from disease in a typical year of $2 \%$ or less with some reporting losses in excess of $6 \%$ (Table 3). Overall, more than $60 \%$ of respondents experienced losses from all sources of disease of $1 \%$ or more of sales. In contrast, approximately $30 \%$ of respondents reported a water shortage in the past decade (Table 3). Adopters were somewhat more likely to have experienced a water shortage than nonadopters. 
Table 3. Respondent Characteristics ${ }^{\mathrm{a}}$

\begin{tabular}{|c|c|c|c|}
\hline & All Respondents & Adopters & Nonadopters \\
\hline Mean years of experience & 25 & 26 & 25 \\
\hline \multicolumn{4}{|l|}{ Job title } \\
\hline Owner & $84 \%$ & $72 \% * * b$ & $88 \% * *$ \\
\hline Head grower/production manager & 7 & $16^{* *}$ & $3^{* *}$ \\
\hline Grower & 3 & 4 & 2 \\
\hline Business manager & 4 & 4 & 3 \\
\hline Other & 3 & 4 & 3 \\
\hline \multicolumn{4}{|l|}{ Education (highest level achieved) } \\
\hline Less than high school & $8 \%$ & $2 \%$ & $10 \%$ \\
\hline High school/GED degree & 26 & 22 & 28 \\
\hline Two-year degree & 10 & 12 & 10 \\
\hline Four-year degree & 38 & $54^{* * *}$ & $32^{* * *}$ \\
\hline Postgraduate degree & 17 & $10^{*}$ & $20^{*}$ \\
\hline \multicolumn{4}{|c|}{ Operations' revenue from all products and services in 2012} \\
\hline Less than $\$ 25,000$ & $24 \%$ & $13 \% * *$ & $28 \% * *$ \\
\hline$\$ 25,001$ to $\$ 100,000$ & 24 & 22 & 25 \\
\hline$\$ 100,001$ to $\$ 250,000$ & 15 & 13 & 15 \\
\hline$\$ 250,001$ to $\$ 500,000$ & 11 & 17 & 9 \\
\hline$\$ 500,001$ to $\$ 750,000$ & 8 & 9 & 8 \\
\hline$\$ 750,001$ to $\$ 1,000,000$ & 4 & 0 & 6 \\
\hline$\$ 1,000,001$ to $\$ 2,000,000$ & 4 & 7 & 3 \\
\hline$\$ 2,000,001$ to $\$ 4,000,000$ & 4 & 9 & 3 \\
\hline$\$ 4,000,001$ to $\$ 6,000,000$ & 3 & 2 & 3 \\
\hline$\$ 6,000,001$ to $\$ 8,000,000$ & 2 & 7 & 1 \\
\hline Greater than $\$ 10,000,000$ & 1 & 2 & 0 \\
\hline \multicolumn{4}{|c|}{ Operations' total costs and nursery costs in 2012} \\
\hline Mean total production costs & $\$ 427,722$ & $\$ 857,772^{* *}$ & $\$ 248,535^{* *}$ \\
\hline Minimum total production costs & 250 & 300 & 250 \\
\hline Maximum total production costs & $7,849,726$ & $7,849,726$ & $4,210,000$ \\
\hline Mean nursery costs & 363,093 & $689,275^{*}$ & $207,092^{*}$ \\
\hline Minimum nursery costs & 100 & 100 & 350 \\
\hline Maximum nursery costs & $7,215,899$ & $7,215,899$ & $4,210,000$ \\
\hline \multicolumn{4}{|c|}{ Number of times operation experienced a water shortage in past 10 years } \\
\hline Never & $69 \%$ & $58 \% *$ & $73 \% *$ \\
\hline One or two times & 20 & $34^{* * *}$ & $15^{* * *}$ \\
\hline Three or four times & 6 & 6 & 6 \\
\hline Five times or more & 4 & 2 & 4 \\
\hline Don't know & 1 & 0 & 1 \\
\hline \multicolumn{4}{|c|}{ Sales revenue lost to disease in typical year } \\
\hline Less than $1 \%$ & $37 \%$ & $28 \%$ & $39 \%$ \\
\hline $1 \%$ to $2 \%$ & 28 & 36 & 25 \\
\hline $3 \%$ to $5 \%$ & 25 & 30 & 24 \\
\hline $6 \%$ to $10 \%$ & 7 & 6 & 7 \\
\hline $11 \%$ to $20 \%$ & 3 & 0 & 4 \\
\hline
\end{tabular}

a Percentage totals may not sum to 100 due to rounding.

${ }^{\mathrm{b}}$ Significant differences between adopters and nonadopters at the $10 \%\left({ }^{*}\right), 5 \%\left({ }^{* *}\right)$, and $1 \%\left({ }^{* * *}\right)$ levels. 
The findings from these descriptive statistics informed the respondent characteristics that are included in the analyses of the choice questions.

\subsection{Analysis of Choice Data}

The 50 respondents who selected "would adopt" for at least one choice question resulted in 89 affirmative responses to choice questions, which leaves 298 responses declining choice alternatives. We estimated conditional logit long and short models, and the random parameters (mixed logit) short model, using these responses to the choice questions.

For all three models, \%cost is negative and significant (Table 4), which supports the standard expectation that as cost increases the likelihood of investing in water recycling declines. The marginal effects for both conditional logit models are approximately the same indicating that this result is robust to the specification of program attributes for water and disease in the equations. Cost is more significant in the mixed logit estimation, and the coefficient is approximately $30 \%$ larger than the estimates in the conditional logit specifications.

None of the water shortage variables are significant in the long conditional logit estimation, nor is the $\uparrow$ watershortage coefficient significant in the short equation for the conditional logit and mixed logit estimation. This result is not surprising given that nearly $70 \%$ of respondents had not experienced water shortages at their operations even though the study area had experienced drought conditions in 7 of the past 10 years (National Oceanic and Atmospheric Administration, National Centers for Environmental Information, 2015). It also may be the case that operations that had experienced water shortages in the past 10 years had taken steps to avoid future shortages; this was the case for two operations we visited. Visits with growers indicated that those who did not have sufficient water supplies in recent drought years had taken actions to remedy this problem.

The coefficients for $14 \%$ disease and $16 \%$ disease are negative and significant in the conditional logit estimation of the long model. The negative signs indicate operations are less likely to adopt recycling due to increases in the likelihood of disease detection. The lack of significance on three of the disease variables is somewhat perplexing. In the study pretesting, growers told us that any increase in disease is unacceptable, which would suggest that $\beta_{14 \% d}$ would likely be significant. Further, it seems illogical that growers are concerned about disease detection levels of $14 \%$ and $16 \%$, but not concerned about higher disease detection levels of $18 \%$ and $20 \%$. Survey respondents indicated that disease was their most serious risk with $80 \%$ indicating plant disease was a very or somewhat important risk. The fact that adoption is not sensitive to increases in the probability of disease detection likely follows from the fact that growers want to avoid any disease. Conversations with growers indicated that they felt their reputation was of paramount importance to the success of their business and 
Table 4. Conditional and Mixed Logit Models of Responses to Choice Questions

\begin{tabular}{|c|c|c|c|c|c|}
\hline & \multirow{2}{*}{\multicolumn{2}{|c|}{$\begin{array}{c}\text { Long Model } \\
\text { Conditional Logit }\end{array}$}} & \multicolumn{3}{|c|}{ Short Model } \\
\hline & & & \multicolumn{2}{|c|}{ Conditional Logit } & \multirow{2}{*}{$\begin{array}{l}\text { Mixed Logit } \\
\text { Coefficient } \\
\text { Estimates }\end{array}$} \\
\hline & $\begin{array}{l}\text { Coefficient } \\
\text { Estimates }\end{array}$ & $\begin{array}{l}\text { Marginal } \\
\text { Effects }\end{array}$ & $\begin{array}{l}\text { Coefficient } \\
\text { Estimates }\end{array}$ & $\begin{array}{l}\text { Marginal } \\
\text { Effects }\end{array}$ & \\
\hline$\%$ cost & $\begin{array}{r}-10.31^{* a} \\
(2.67)^{\mathrm{b}}\end{array}$ & $\begin{array}{r}-1.67^{*} \\
(0.41)\end{array}$ & $\begin{array}{r}-9.95^{*} \\
(1.96)\end{array}$ & $\begin{array}{r}-1.62^{*} \\
(0.288)\end{array}$ & $\begin{array}{c}-13.17^{* * *} \\
(4.06)\end{array}$ \\
\hline $10 \%$ watershortage & $\begin{array}{c}0.20 \\
(0.66)\end{array}$ & $\begin{array}{c}0.03 \\
(0.12)\end{array}$ & & & \\
\hline $13 \%$ watershortage & $\begin{array}{c}0.38 \\
(0.58)\end{array}$ & $\begin{array}{c}0.07 \\
(0.11)\end{array}$ & & & \\
\hline $17 \%$ watershortage & $\begin{array}{c}0.15 \\
(0.38)\end{array}$ & $\begin{array}{c}0.03 \\
(0.07)\end{array}$ & & & \\
\hline $20 \%$ watershortage & $\begin{array}{c}0.06 \\
(0.38)\end{array}$ & $\begin{array}{c}0.01 \\
(0.06)\end{array}$ & & & \\
\hline $12 \%$ disease & $\begin{array}{r}-0.26 \\
(0.36)\end{array}$ & $\begin{array}{r}-0.04 \\
(0.05)\end{array}$ & & & \\
\hline $14 \%$ disease & $\begin{array}{c}-1.05^{* *} \\
(0.47)\end{array}$ & $\begin{array}{r}-0.13^{*} \\
(0.04)\end{array}$ & & & \\
\hline $16 \%$ disease & $\begin{array}{c}-0.79^{* * *} \\
(0.46)\end{array}$ & $\begin{array}{c}-0.10^{* *} \\
(0.05)\end{array}$ & & & \\
\hline $18 \%$ disease & $\begin{array}{r}-0.73 \\
(0.51)\end{array}$ & $\begin{array}{r}-0.10^{*} \\
(0.06)\end{array}$ & & & \\
\hline $20 \%$ disease & $\begin{array}{r}-0.82 \\
(0.64)\end{array}$ & $\begin{array}{r}-0.11 \\
(0.07)\end{array}$ & & & \\
\hline$\uparrow w a t e r s h o r t a g e$ & & & $\begin{array}{c}0.05 \\
(0.23)\end{array}$ & $\begin{array}{c}0.01 \\
(0.04)\end{array}$ & $\begin{array}{r}-0.80 \\
(0.94)\end{array}$ \\
\hline$\uparrow$ disease & & & $\begin{array}{c}-0.60^{* *} \\
(0.25)\end{array}$ & $\begin{array}{c}-0.10^{* *} \\
(0.40)\end{array}$ & $\begin{array}{c}-3.49^{* *} \\
(1.46)\end{array}$ \\
\hline owner*asc & $\begin{array}{c}-0.71^{* *} \\
(0.33)\end{array}$ & $\begin{array}{c}-0.12^{* *} \\
(0.06)\end{array}$ & $\begin{array}{c}-0.67^{* *} \\
(0.30)\end{array}$ & $\begin{array}{c}-0.11^{* *} \\
(0.05)\end{array}$ & $\begin{array}{c}-2.42^{* *} \\
(1.18)\end{array}$ \\
\hline college* asc & $\begin{array}{c}0.14 \\
(0.27)\end{array}$ & $\begin{array}{c}0.02 \\
(0.04)\end{array}$ & $\begin{array}{c}0.14 \\
(0.26)\end{array}$ & $\begin{array}{c}0.02 \\
(0.04)\end{array}$ & $\begin{array}{c}0.14 \\
(0.96)\end{array}$ \\
\hline highrevenue* asc & $\begin{array}{l}0.59^{* *} \\
(0.27)\end{array}$ & $\begin{array}{l}0.10^{* *} \\
(0.05)\end{array}$ & $\begin{array}{l}0.54^{* *} \\
(0.26)\end{array}$ & $\begin{array}{l}0.09^{* *} \\
(0.05)\end{array}$ & $\begin{array}{c}0.65 \\
(0.94)\end{array}$ \\
\hline watershortage $^{*}$ asc & $\begin{array}{c}0.09 \\
(0.09)\end{array}$ & $\begin{array}{c}0.02 \\
(0.01)\end{array}$ & $\begin{array}{c}0.10 \\
(0.08)\end{array}$ & $\begin{array}{c}0.02 \\
(0.01)\end{array}$ & $\begin{array}{c}0.55 \\
(0.34)\end{array}$ \\
\hline diseaseloss*asc & $\begin{array}{r}-0.05 \\
(0.05)\end{array}$ & $\begin{array}{r}-0.01 \\
(0.01)\end{array}$ & $\begin{array}{r}-0.05 \\
(0.05)\end{array}$ & $\begin{array}{r}-0.01 \\
(0.01)\end{array}$ & $\begin{array}{r}-0.16 \\
(0.18)\end{array}$ \\
\hline $\begin{array}{l}\text { Standard deviations } \\
\uparrow w a t e r s h o r t a g e\end{array}$ & random para & neters & & & $\begin{array}{l}4.00^{* * *} \\
(1.19)\end{array}$ \\
\hline$\uparrow$ disease & & & & & $\begin{array}{l}6.11^{* * *} \\
(1.70)\end{array}$ \\
\hline $\mathrm{N}$ & 1,0 & & & & 1,062 \\
\hline Log likelihood & -23 & .83 & -2 & .33 & -192.70 \\
\hline
\end{tabular}


Table 4. Continued

\begin{tabular}{lclllll}
\hline \hline & \multicolumn{2}{c}{ Long Model } & & \multicolumn{2}{c}{ Short Model } \\
\cline { 2 - 3 } & \multicolumn{2}{c}{ Conditional Logit } & & Conditional Logit & Mixed Logit \\
\cline { 2 - 3 } & Coefficient & Marginal & & Coefficient & Marginal & Coefficient \\
& Estimates & Effects & & Estimates & Effects & Estimates \\
\hline AIC & 499.66 & & 488.66 & 405.40 \\
BIC & 574.18 & & 528.40 & 455.08 \\
\hline \hline
\end{tabular}

${ }^{a}$ Asterisks denote significance at the $10 \%\left({ }^{*}\right), 5 \%\left({ }^{* *}\right)$, and $1 \%\left({ }^{* * *}\right)$ levels.

${ }^{\mathrm{b}}$ Standard errors are reported in parentheses.

'Sample sizes are based on three observations per choice question. Some observations are excluded because of missing observations on respondent characteristics.

Note: AIC, Akaike information criterion; BIC, Bayesian information criterion.

they did not want to sell any diseased plants to customers that might undermine customer confidence in their operations.

In this light, it is worth noting that all of the disease coefficients except $12 \%$ disease are approximately the same magnitude, ranging from -0.7 to -1.0 . Further, even though the coefficient on $12 \%$ is somewhat smaller than the coefficients for the other four levels of disease detection, the large standard errors on the coefficient estimates suggests that this coefficient may not be significantly different from the coefficients for disease detection levels of $14 \%, 16 \%, 18 \%$, and $20 \%$.

Given the observed pattern of results in the long model, in which none of water shortage variables are significant and only two of the disease variables are significant, we tested the joint hypothesis that the levels of the water shortage increase and disease detection variables are not significantly different from the current (status quo) conditions of $15 \%$ water shortage and $10 \%$ disease detection (see Table 1):

$$
\begin{aligned}
\mathrm{H}_{0}: & \beta_{10 \% w s}=\beta_{13 \% w s}=0 \\
\beta_{17 \% w s} & =\beta_{20 \% w s}, \text { and } \beta_{12 \% d}=\beta_{14 \% d}=\beta_{16 \% d}=\beta_{18 \% d}=\beta_{20 \% d}
\end{aligned}
$$

versus

$$
\mathrm{H}_{1}: \operatorname{not} \mathrm{H}_{0} \text {. }
$$

The insight behind this joint hypothesis is that the increased probability of water shortage or disease affects adoption decisions, but the decisions are not affected by the magnitude of the increased risk. If sample size is a consideration, as discussed previously, it may be appropriate to simply test whether an increase in the incidence of water shortage or disease detection affects choices to adopt water recycling. 
The hypothesis is tested by a comparison of the conditional logit estimation of the long and short models, and the $\chi^{2}$ statistic is 3.00, which is not significant at the $10 \%$ level $\left(\chi^{2}=12.02\right.$, degrees of freedom $\left.=7\right)$; therefore, the null hypothesis cannot be rejected. This result provides further confirmation that growers are not concerned about water shortage and are concerned about increased disease detection probability, but we cannot detect a nonzero marginal effect as the probability of disease detection increases.

For policy discussions, we will reference the short model. Here we test:

$$
\mathrm{H}_{0}: \beta_{\uparrow w s}=0 \text { versus } \mathrm{H}_{1}: \beta_{\uparrow w s} \neq 0
$$

and

$$
\mathrm{H}_{0}: \beta_{\uparrow d}=0 \text { versus } \mathrm{H}_{1}: \beta_{\uparrow d} \neq 0,
$$

where $\uparrow w$ s denotes $\uparrow$ watershortage and $\uparrow d$ denotes $\uparrow$ disease. We cannot reject the null hypothesis for $\uparrow w s$, and the null hypothesis is rejected for $\uparrow d$. These results hold for the conditional logit and the mixed logit estimation of the short model. The standard deviations of the estimates of $\uparrow w s$ and $\uparrow d$ are both significant in the mixed logit estimation.

In terms of respondent characteristics in the short models, owners are significantly less likely to adopt recycling and larger firms (in terms of revenue) are more likely to adopt recycling in the conditional logit estimation, but only the owner characteristic remains significant in the mixed logit estimation. These are characteristics that will affect a respondent choosing to adopt recycling independent of the attributes and their levels in the choice questions. It is noteworthy that experience with water shortage (expwatershortage) or disease (expdiseaseloss) was not significant in either estimation.

\subsection{Compensation to Adopt Recycling}

The estimation results reported previously indicate that there is no natural nudge for growers to invest in water recycling due to concerns about drought. This means that because recycling is costly, growers will require incentives or coercive polices to motivate them to adopt water recycling. The coefficient estimates provide estimates of the mean incentives. The log likelihood, Akaike information criterion (AIC), and Bayesian information criterion (BIC) statistics indicate that the short models fit the data better than the long model, and we will use the results from the short models in this discussion. ${ }^{13}$

The absolute value of the ratio of the coefficient on $\uparrow$ disease to the coefficient on \% cost in the conditional logit model provides an estimate of the magnitude of the average monetary incentive, in percentage terms, that growers would need to receive to adopt water recycling. This is calculated for the conditional logit

13 A larger log likelihood and smaller AIC and BIC statistics indicate a better fitting model for the data used for estimation. 
and mixed logit estimations, respectively, as follows:

$$
\begin{aligned}
& \widehat{\mathrm{ocost}_{c l}}=\left|\frac{\beta_{\uparrow d}}{\beta_{\% c}}\right| \text { and } \\
& \widehat{\% \operatorname{cost}}_{m l}=\left|\frac{E\left(\beta_{\uparrow d}\right)}{\beta_{\% c}}\right|,
\end{aligned}
$$

where $E$ is the expectation operator of the distributed parameter estimate on the disease detection increase variable.

For the conditional logit estimation, the result of this calculation is 0.06 or $6 \%$, with a standard error of 0.027 , and comparable figures for the mixed logit estimation are 0.265 or $26 \%$. The $90 \%$ confidence intervals for these estimates are $(0.015,0.104)$ and $(0.051,0.479)$, respectively. These numbers indicate that operations would need to be compensated $6 \%$ or $26 \%$ of their annual nursery production costs to adopt water recycling. This translates into a $\$ 6,000$, or $\$ 26,000$, incentive for an operation with annual nursery production costs of $\$ 100,000$ and $\$ 60,000$, or $\$ 260,000$, for an operation with $\$ 1,000,000$ in nursery production costs.

Which of the models provides the best estimate? The mixed logit model has the highest log likelihood, indicating that this estimation fits the data better than the conditional logit estimation. Both the AIC and the BIC criteria also favor the mixed logit model. Thus, we would favor the $26 \%$ figure for policy analyses.

Ferraro (2015) analyzed nurseries that used well water, municipal water, or recycled water as their primary source for irrigation. For a small nursery with low-cost access to well water and annual gross revenues of slightly more than $\$ 100,000$, substituting recycled water for well water would increase annual costs by some $\$ 21,000$ (Ferraro, 2015). The $\$ 26,000$ figure suggested here would be sufficient to compensate for the increased cost plus a risk premium.

\section{Discussion and Conclusions}

Controlling costs is an important consideration for growers. Discussions with growers indicate that many feel they are price takers with market prices largely influenced by sales at big-box stores. Thus, the cost of installing and operating water recycling technology is an important consideration for growers as they may perceive that they have limited ability to pass increased costs on to their customers. Most growers are not currently equipped to recycle irrigation water, and $77 \%$ of growers responding to the survey indicated that cost would be very or somewhat important in their decision to adopt water recycling.

Our findings indicate that producers are not concerned about drought and are concerned about disease; therefore, a "nudge" to stimulate voluntary water recycling is not present, and the possibility of spreading disease presents a significant disincentive to invest in water recycling. If the goal of the USEPA 
and state environmental agencies is to reduce NPS pollution from nursery operations, our research indicates that financial incentives or coercive policies will be needed to stimulate widespread adoption of water recycling in the MidAtlantic region. The most likely action from the USDA might be to recommend best management practices for recycling irrigation water combined with technical and financial support for adoption. Adoption of best management practices for water recycling might be stimulated by a source like the USDA's Environmental Quality Incentives Program (http://www.nrcs.usda.gov/wps/portal/nrcs/main/ national/programs/financial/eqip/), which provides incentives for farmers to undertake environmentally desirable actions. For example, Buckley and Obropta (2006) found that water recycling reduced nutrient loads in an adjacent stream by $25 \%$.

The incentive program might include educational efforts to promote the local and regional benefits of water recycling and technical assistance to help growers and their employees successfully implement the new technology. The best management practices may include recommendations and education for how operations can adopt water recycling without increasing the risk of disease (Ghimire et al., 2011; Hong, 2011; Hong, Richardson, and Kong, 2003).

In addition, parallel research in the Mid-Atlantic area indicates that final customers may be willing to pay a price premium for plants that are produced with water conservation practices, which would be consistent with water recycling, or for plants that are certified as disease free (Hartter, 2012). Thus, just as the industry currently has labels for ornamental horticulture products such as the "Knock Out Rose ${ }^{\circledR}$," the industry might consider a water conservation or disease-free certification program to help growers recapture costs through increased prices paid by consumers for plants.

\section{References}

Bederli, T., and A. Brouwer, "Nonmarket Valuation of Water Quality in a Rural Transition Economy in Turkey Applying a Posteriori Bid Design.” Water Resources Research 43(2007):W05436. doi:10.1029/2006WR004869.

Buckley, K., and C.C. Obropta. "The Tailwater Recovery System as an Agricultural BMP - Improving Effectiveness and Other Lessons Learned.” Proceedings of the 2006 USDA-CSREES National Water Quality Conference, 2006. Internet site: http://www. usawaterquality.org/conferences/2006/abstracts/buckley.pdf (Accessed November 6, 2015).

Carmines, E.G., and R.A. Zeller. Reliability and Validity Assessment. Newbury Park, CA: Sage, 1979.

Collins, A.T., J. M. Rose, and M.C.J. Bliemer. "Ngene - The Cutting Edge in Experimental Design for Stated Choice Experiments.” Sydney, Australia: Institute of Transport and Logistics Studies, University of Sydney, 2007.

Commonwealth of Virginia. Chesapeake Bay TMDL: Phase I Watershed Implementation Plan. November 29, 2010. Internet site: http://www.deq.virginia.gov/Portals/0/DEQ/ Water/TMDL/Baywip/vatmdlwipphase1.pdf (Accessed September 13, 2013). 
Czap, N.V., H.J. Czap, G.D. Lynne, and M.E. Burbach. "Walk in My Shoes: Nudging for Empathy Conservation." Ecological Economics 118(2015):147-58.

Dillman, D.A., J.D. Smyth, and L.M. Christian. Internet, Mail, and Mixed-Mode Surveys: The Tailored Design Method. Hoboken, NJ: Wiley, 2008.

Ferraro, N.K. "Economic Analysis of Recapturing and Recycling Irrigation Techniques on Horticulture Nurseries.” Master's thesis, Virginia Tech, Blacksburg, 2015.

Ghimire, S.R., P.A. Richardson, P. Kong, J. Hu, J.D. Lea-Cox, D.S. Ross, G.W. Moorman, and C. Hong. "Distribution and Diversity of Phytophthora Species in Nursery Irrigation Reservoir Adopting Water Recycling System during Winter Months.” Journal of Phytopathology 159(2011):713-19.

Hartter, D.L. "Understanding Consumers' Ornamental Plant Preferences for Disease-Free and Water Conservation Labels.” Master's thesis, Virginia Tech, Blacksburg, 2012.

Holmes, T.P., and W.L. Adamowicz. "Attribute-Based Methods.” A Primer on Nonmarket Valuation. P.A. Champ, K J. Boyle, and T.C. Brown, eds. Dordrecht, The Netherlands: Kluwer Academic, 2003, pp. 171-219.

Hong, C.X. "Mitigating Irrigation Pathogens without Water Treatment." Proceedings of the 36th Annual Meeting of the International Plant Propagators' Society-Southern Region of North America, 2011. Internet site: http://ipps-srna.org/pdf/2011Papers/ 4-\%20Hong-Chuan-2011.pdf (Accessed November 15, 2014).

Hong, C.X., and G.W. Moorman. "Plant Pathogens in Irrigation Water: Challenges and Opportunities." Critical Reviews in Plant Sciences 24,3(2005):189-208.

Hong, C.X., P.A. Richardson, and P. Kong. "Decline in Populations of Phytophthora spp. with Increasing Distance from a Runoff Water Entry Point in a Retention Pond." Phytopathology 93,S6 (2003):S36.

Moorman, G. "Phytophthora Root Rot on Woody Ornamentals." Plant Disease Fact Sheets, Penn State Extension, The Pennsylvania State University. Internet site: http://extension. psu.edu/pests/plant-diseases/all-fact-sheets/phytophthora-root-rot-on-woodyornamentals (Accessed October 11, 2013a).

Moorman, G. "Pythium.” Plant Disease Fact Sheets, Penn State Extension, The Pennsylvania State University. Internet site: http://extension.psu.edu/plant-disease-factsheets/ all-fact-sheets/pythium (Accessed October 11, 2013b).

National Oceanic and Atmospheric Administration, National Centers for Environmental Information. "Climate at a Glance: Time Series." Internet site: http://www.ncdc.noaa.gov/ cag/time-series/us (Accessed November 2, 2015).

National Oceanic and Atmospheric Administration, National Weather Service Internet Services Team. "Advanced Hydrologic Prediction Service." Internet site: http://water.weather.gov/precip/ (Accessed October 15, 2012).

Omondi, I., I. Baltenweck, A.G. Drucker, G. Obare, and K.K. Zander. "Economic Valuation of Sheep Genetic Resources: Implications for Sustainable Utilization in the Kenyan Semi-Arid Tropics." Tropical Animal Health and Production 40(2008):615-26.

Pimentel, D., J. Houser, E. Preiss, O. White, H. Fang, L. Mesnick, T. Barsky, S. Tariche, J. Schreck, and S. Alpert. "Water Resources: Agriculture, the Environment, and Society." BioScience 47,2(1997):97-106.

Scarpa, R., A.G. Drucker, S. Anderson, N. Ferraes-Ehuan, V. Gómez, C.R. Risopatrón, and O. Rubio-Leonel. "Valuing Genetic Resources in Peasant Economies: The Case of 'Hairless' Creole Pigs in Yucatan.” Ecological Economics 45(2003a):427-43.

Scarpa, R., E.S.K. Ruto, P. Kristjanson, M. Radeny, A.G. Drucker, and J.E.O. Rege. "Valuing Indigenous Cattle Breeds in Kenya: An Empirical Comparison of Stated and Revealed Preference Value Estimates.” Ecological Economics 45(2003b):409-26. 
U.S. Department of Agriculture (USDA). 2007 Census of Agriculture: United States Summary and State Data. Vol. 1, Geographic Area Series, Part 51, 2009. Internet site: http://www. agcensus.usda.gov/Publications/2007/ (Accessed October 16, 2015).

U.S. Department of Agriculture (USDA). 2012 Census of Agriculture: Appendix A. Census of Agriculture Methodology. 2014a. Internet site: http://www.agcensus.usda. gov/Publications/2012/Full_Report/Volume_1,_Chapter_1_US/usappxa.pdf (Accessed October 16, 2015).

U.S. Department of Agriculture (USDA). 2012 Census of Agriculture: Farm and Ranch Irrigation Survey (2013). Vol. 3, Special Studies, Part 1, 2014b. Internet site: http://www.agcensus.usda.gov/Publications/2012/Online_Resources/Farm_and_ Ranch_Irrigation_Survey/ (Accessed October 16, 2015).

U.S. Department of Agriculture (USDA). 2012 Census of Agriculture: United States Summary and State Data. Vol. 1, Geographic Area Series, Part 51, 2014c. Internet site: http://www.agcensus.usda.gov/Publications/2012/Full_Report/Volume_1,_Chapter_1_ US/usv1.pdf (Accessed October 16, 2015).

U.S. Environmental Protection Agency (USEPA). Chesapeake Bay TMDL Executive Summary. 2010. Internet site: http://www2.epa.gov/sites/production/files/2014-12/ documents/bay_tmdl_executive_summary_final_12.29.10_final_1.pdf (Accessed October 10, 2015).

Valentine, K. "Federal Appeals Court Rules against Groups Trying to Block the Clean Up of the Chesapeake Bay." Climate Progress. July 6, 2015. Internet site: http://thinkprogress.org/climate/2015/07/06/3677227/chesapeake-bay-cleanupopinion/ (Accessed September 1, 2015).

Zander, K.K., and A.G. Drucker. "Conserving What's Important: Using Choice Model Scenarios to Value Local Cattle Breeds in East Africa." Ecological Economics 68(2008):34-45. 